\title{
PRIVATIZACIJA PREDUZEĆA ZA TELEKOMUNIKACIJE TELEKOM SRBIJA A.D. BEOGRAD U SVETLU SUMNJE U EFIKASNO KORPORATIVNO UPRAVLJANJE
}

\author{
Nebojša Jeremić ${ }^{1 *}$, Selim Lika² \\ ${ }^{1}$ Telekom Srbija a.d., Takovska 2, Beograd, Srbija \\ ${ }^{2}$ Ministarstvo vanjskih poslova i evropskih integracija Crne Gore, Stanka Dragojevića 2, Podgorica, Crna Gora
}

\section{Apstrakt:}

Privatna svojina i tržište su osnovni postulati uspešne privrede i održivog ekonomskog sistema, ali ne bi trebalo zanemariti ni ulogu države. Naime, ona igra presudnu ulogu u stvaranju regulatornog okvira, saniranju negativnog uticaja prodaje važnog mrežnog resursa kako na nacionalno tržište, tako i na budući održivi razvoj privrede i ekonomije. Upravljanje privrednim sistemima sa većinskim državnim vlasništvom suštinski se ne razlikuje mnogo od upravljanja privrednim društvima u privatnom sektoru. Ekonomičnost, efektivnost i ostali ekonomski zakoni su od fundamentalne važnosti u oba sektora. Specifičnost korporativnog upravljanja u privrednim društvima sa većinskim državnim vlasništvom proističe iz paradoksalne situacije u kojoj se država javlja i kao učesnik i regulator na finansijskom tržištu. Zakonski okvir rada preduzeća za telekomunikacije Telekom Srbija u velikoj meri je regulisan odredbama Zakona o elektronskim komunikacijama i odlukama RATEL-a. Društva u kojima je država većinski vlasnik kontraverzna su i u pogledu ciljeva, jer su usmerena ne samo ka ostvarivanju profita već i na brojne neekonomske, socijalne, ekološke, društvene, regionalne, političke ciljeve u različitim oblastima. Loša strana ovih uticaja ogleda se u slabljenju odgovornosti i motvacije korporativnih organa društava čiji je većinski vlasnik država. U radu se ispituje da li je prodaja preduzeća Telekom Srbija posledica sumnje u efikasnost korporativnog upravljanja, kao i da li se pasivno ponašanje države kao vlasnika može generalizovati i primeniti na ovo privredno društvo.
\end{abstract}

\section{Ključne reči:}

telekomunikacije,

vlasništvo,

Evropa,

korporativno upravljanje.

\section{UVOD}

Privatizacija je postupak u okviru koga država prepušta privatnom sektoru pružanje usluga i/ili proizvodnju dobara. Tokom XX veka, a posebno nakon Drugog svetskog rata, država je preuzela odgovornost privatnog sektora za funkcionisanje i razvoj oblasti značajnih za ljudsko društvo, kao što su: obrazovanje, bezbednost, zdravstvena zaštita, komunalne usluge i izgradnja vitalnih infrastrukturnih sistema. Sa završetkom Hladnog rata, ovo klatno se pomerilo na drugu stranu. Pitanje transformacije državne svojine u kapitalističkim zemljama na principima neoliberalnog kapitalizma i Fridmanove teorije o ekonomskim odnosima otvorio je u Sjedinjenim Američkim Državama Ronald Regan, a u Evropi Margaret Tačer. Upravo je privatizacija telekomunikacionih sistema bila „inicijalna kapisla“ novog trenda, s obzirom da je 1984. godine uspešno privatizovan British Telecom, ta privatizacija je najslikovitije opisala ekonomsku politiku britanske vlade i njene premijerke tzv. tačerizam. Nakon pada Berlinskog zida 1989. godine, propasti SSSR-a i širenja kapitalizma na evropske zemlje bivšeg socijalističkog uređenja i planske privrede, postavilo se pitanje ukidanja društvene (državne) svojine. $U$ sklopu nove ekonomske doktrine, smatra se da država nije dobar poslodavac, odnosno da u postojećim tržišnim uslovima ne može da bude konkurentna privatnom sektoru.
Reforme tranzicionih zemalja Evrope, koje su bile u istočnom bloku, išle su ka modernizaciji, privatizaciji i restrukturiranju posrnulih industrija tj. stvaranju nove privredne strukture. Stručna javnost (Nikolić \& Kovačević, 2014, str. 63-86) saglasna je da model privatizacije, koji je u Srbiji bio na snazi u XXI veku kako u privredi, tako i industriji Srbije, nije doneo pozitivne rezultate i performanse. Privatizacija je delom pokrenula restrukturiranje preduzeća u pojedinim oblastima industrije. Donela je svež kapital, nove tehnologije i nova menadžerska znanja. Međutim, njen rezultat je daleko slabiji od očekivanog. Ovaj proces je posebno osetljiv kada je reč o transformaciji velikih sistema, kao što su i telekomunikacije. Pristup privatizacije mrežnih sistema i telekomunikacionog sektora, ne samo u Srbiji, već i u Evropi, nužno je multidisciplinarnog karaktera i uključuje razmatranje tehnološke, strateške, ekološke, regionalne i ekonomske dimenzije različitih opcija. Telekomunikacije su bile tipična infrastrukturna delatnost koja je donedavno u svetu bila isključivo državni monopol. U razvijenim tržišnim privredama intenzivirao se talas privatizacije velikih državnih privrednih sistema, neprikosnovenih monopola poslednje dve decenije $\mathrm{XX}$ veka, kao rezultat dominirajuće neoliberalne ekonomske škole. Globalizacija i regionalne integracije su bili dodatni faktori koji su uticali na deregulaciju u međunarodnim odnosima, berzama i na tržištima kapitala. 


\section{REZULTATI I DISKUSIJA}

\section{Poslovanje i privatizacija evropskih telekomunikacionih operatera}

Početkom XXI veka, naučno-tehnološka revolucija je iznedrila informaciono-komunikacione tehnologije (u nastavku IKT) kao svojevrsnu glavnu lokomotivu razvoja privreda i društvenih zajednica. To su potvrdila ne samo brojna istraživanja međunarodnih institucija, akademskih ustanova, već i praksa da su najtraženija zanimanja softver i sistem inženjera. U skladu sa tendencijama, pretpostavka dostupnosti i razvoja opšte dostupnosti telekomunikacionih usluga predstavlja generator održivog razvoja i povećanja BDP-a. IKT biznis tržište je u ranoj fazi razvoja u Srbiji: većina preduzeća sama upravlja svojim IKT uslugama, a neka od njih ovakve usluge još ne smatra potrebnim. Očekuje se da će paralelno sa sazrevanjem tržišta sve više preduzeća primeniti outsource strategiju za IKT usluge. Sve to navodi na zaključak da će se povećati produktivnost rada, preko intenziviranja ulaganja u infrastrukturu. Tržište telekomunikacija i IT usluga se konvergira u IKT, a stvaranja novih kompanija dovodi do novih aktivnosti, zapošljavanja IT stručnjaka i smanjenje nezaposlenosti, otvaranjem najstručnijih radnih mesta. Multiplikativni efekti kroz uvođenje naprednih inovacija, e-uprave, poboljšanje obrazovanja, unapređenje zdravstva, vojne tehnologije, ravnomernijeg ruralnog i regionalnog razvoja svakako vodi povećanju prikupljenih javnih prihoda države, a smanjenju troškova birokratskog aparata. Istraživanja su čak i kvantitativno potkrepila dinamiku privrednog rasta i pokazuju da nerazvijene zemlje povećavaju penetraciju telekomunikacionog pristupa (termin koji označava broj korisnika telekomunikacionih usluga na 100 građana) od $10 \%$ posledično vodi rastu bruto društvenog proizvoda (BDP) za 1,38\% (Malinić \& Milićević, 2012, str. 2-15).

Rezultati britanske vlade u privatizaciji 80 -tih godina XX veka, podstakli su i tržišno najrazvijenije zemlje da započnu izlazak iz vlasništva velikih državnih telekomunikacionih sistema, a putem inicijalne javne ponude deonica društva (Initial Public Offering (IPO). Korporacija France Telecom je privatizovana kroz inicijalnu javnu ponudu u četiri koraka. Prva dva poziva za otkup akcija su se desila 1997. i 1998. godine, kada je 34.8\% učešća pušteno na berzu. U 2004. godini, drugih $10.85 \%$ kompanijskih akcija su puštene kroz inicijalnu javnu ponudu, praćene sa dve tranše od ukupno $11.2 \%$ u 2005. i 2007. Ostale dodatne akcije (oko 2.5\%) su prodate zaposlenima korporacije tokom 90 -tih godina. Francuska država danas ima 27.3\% učešća. Pojedina istraživanja (Gasmi et al., 2012), pokazuju prilično negativna iskustva u privatizaciji telekomunikacionih kompanija u periodu od 1985-2008. godine. Od analiziranih 108 zemalja samo su zemlje OECD (odnosno najrazvijenije zemlje) imale pozitivne efekte, dok su druge zemlje imale zanemarljivo pozitivne, ili pak negativne efekte. Prodaja državnih telekomunikacionih operatera u zemljama u razvoju je ekvivalentna prodaji cele putne mreže u oblasti saobraćaja. Vodeći telekomunikacioni operatori u Evropi su nakon sprovedenih privatizacija, ili javnih ponuda akcija, izvršili privatizaciju telekomunikacionih operatora $\mathrm{u}$ manjim zemljama, o čemu navodimo neke primere. France Telecom je kupio 100 odsto udela britanske kompanije Orange (6 miliona pretplatnika), u belgijskom Mobistaru ima 50,9 odsto (1,1 milion pretplatnika), u PTK iz Poljske 34 odsto (0,9 miliona pretplatnika), u Globalu iz Slovačke 64 odsto (0,5 mi-
Tabela 1. Pregled 20 najvećih evropskih telekomunikacionih operatera i ostvareni prihod u 2012. godini

\begin{tabular}{|c|c|c|c|}
\hline $\begin{array}{c}\text { Pozi- } \\
\text { cija }\end{array}$ & Kompanija & Država & $\begin{array}{c}\text { Prihodi u } \\
\text { milionima } \\
\text { evra }\end{array}$ \\
\hline 1 & Deutsche Telekom & Nemačka & 60132 \\
\hline 2 & Telefonica & Španija & 57061 \\
\hline 3 & Vodafone & Velika Britanija & 41436 \\
\hline 4 & Orange & Francuska & 40981 \\
\hline 5 & Telecom Italia & Italija & 23407 \\
\hline 6 & $B T$ & Velika Britanija & 21537 \\
\hline 7 & Telenor & Norveška & 13336 \\
\hline 8 & $K P N$ & Holandija & 11568 \\
\hline 9 & Tella Sonera & Švedska & 11011 \\
\hline 10 & SFR & Francuska & 10199 \\
\hline 11 & Swisscom & Švajcarska & 9317 \\
\hline 12 & Everything Everywhere & Velika Britanija & 7634 \\
\hline 13 & Belgacom & Francuska & 6318 \\
\hline 14 & Turk Telecom & Austrija & 5231 \\
\hline 15 & Virgin Media & Švedska & 4852 \\
\hline 16 & Bouygues Telecom & Francuska & 4664 \\
\hline 17 & Telekom Austria & Austrija & 4184 \\
\hline 18 & Tele2 & Švedska & 3452 \\
\hline 19 & Portugal Telecom & Portugalija & 2911 \\
\hline 20 & $T D C$ & Danska & 2090 \\
\hline
\end{tabular}

Izvor: Europe's telecommunications network operators, Annual Economic Report 2014, str. 16

https://www.etno.eu/datas/publications/economic-reports/ETNO_ Annual_Economic_Report_2014_FINAL_21012015.pdf

liona pretplatnika), u rumunskom Mobilromu 67,8 odsto $(0,7$ miliona pretplatnika). Španska Telefonica je četvrta u svetu po broju korisnika i šesta po tržišnoj vrednosti u svom sektoru. Telefonica zahvata 75 odsto domaćeg tržišta. Ima značajno prisustvo u 15 , dok operiše u skoro 40 zemalja sveta. Godine 2006. Telefonica je kupila Telekom Češke, a u China Netcom u poseduje $5 \%$ akcija. Najveći deo vlasništva nad kompanijom je u rukama države, ali akcionari su i veliki kapitalni investicioni fondovi kao JP Morgan Chase, BBVA, LaCaixa, Citybank i CapitalGroup. Većinski paket akcija grčkog operatora OTE kupio je Deutsche Telecom. Država je zadržala pravo glasa u OTE, kako bi obezbedila vitalne nacionalne interese u sektoru telekomunikacija (Paunović, 2010).

U vezi sa privatizacijom telekomunikacionih kompanija na ovim prostorima, ne sme se zanemariti ni činjenica da su države koje su prodavale telekomunikacione kompanije pratili veliki korupcionaški skandali. Naime, Magyar Telekom i Deutsche Telekom, koji su privatizovali makedonski i crnogorski Telekom, platili su blizu 100 miliona USD u vansudskoj pogodbi sa US Securitiesand Exchange Commission (SEC) koja je identifikovala koruptivne elemente u transakcijama privatizacije (Sutherland, 2012).

\section{Osnovni podaci o vlasničkoj strukturi i upravljanju preduzecem Telekom Srbija}

Telekom Srbija je vodeće, a u potpunosti domaće privredno telekomunikaciono društvo, koje od osnivanja blizu dve decenije ima ulogu lidera u oblasti telekomunikacija, $\mathrm{i}$ to $\mathrm{u}$ svim segmentima: fiksna, IPTV, mobilna telefonija, internet. 
Tabela 2. Pregled privatizacija telekomunikacionih operatora u našem regionu

\begin{tabular}{|c|c|c|c|c|c|}
\hline Zemlja & Kompanija & Godina & Metodologija privatizacije & $\begin{array}{c}\text { Procenat privatiz. } \\
\text { kapitala }\end{array}$ & Strateški partner \\
\hline Bugarska & BTC & 2004 & Strateška prodaja & $65 \%$ & SAGA Capital i Advent \\
\hline \multirow{2}{*}{ Hrvatska } & \multirow{2}{*}{$H T$} & 1999 & Strateška prodaja & $35 \%$ & Deutsche Telekom \\
\hline & & 2001 & Strateška prodaja & $16 \%$ & Deutsche Telekom \\
\hline \multirow{2}{*}{ Češka } & \multirow{2}{*}{ Cesky } & 1995 & Strateška prodaja & $27 \%$ & KPN Swisscom \\
\hline & & 1995 & IPO (Inicijalna javna ponuda) & $15 \%$ & Institucionalni investitori $^{\star}$ \\
\hline \multirow{2}{*}{ Estonija } & \multirow{2}{*}{ Esti Telekom } & 1992 & Strateška prodaja & $49 \%$ & Tella Sonera \\
\hline & & 1999 & IPO & $23,70 \%$ & Institucionalni investitori ${ }^{\star}$ \\
\hline \multirow{4}{*}{ Mađarska } & \multirow{4}{*}{ Matav } & 1993 & Strateška prodaja & $31 \%$ & Deutsche Telekom \\
\hline & & 1995 & Strateška prodaja & $37 \%$ & Deutsche Telekom \\
\hline & & 1997 & IPO & $26 \%$ & Institucionalni investitori ${ }^{\star}$ \\
\hline & & 1999 & SPO (Sekundarna javna ponuda) & $6 \%$ & Institucionalni investitori ${ }^{\star}$ \\
\hline Letonija & Lattelecom & 1993 & Strateška prodaja & $49 \%$ & $C+W$, Sonera \\
\hline \multirow{2}{*}{ Litvanija } & Lietuvos & 1992 & Strateška prodaja & $49 \%$ & Tella Sonera \\
\hline & Telekoms & 2000 & IPO & $25 \%$ & Institucionalni investitori ${ }^{\star}$ \\
\hline Makedonija & Maktel & 2001 & Strateška prodaja & $51 \%$ & Deutsche Telekom \\
\hline \multirow{2}{*}{ Poljska } & \multirow{2}{*}{ TPSA } & 1998 & IPO & $15 \%$ & ${\text { Institucionalni investitori }{ }^{\star}}^{*}$ \\
\hline & & 2000 & Strateška prodaja & $35 \%$ & $F T$ \\
\hline Rumunija & Romtelecom & 1998 & Strateška prodaja & $60 \%$ & OTE \\
\hline Srbija & Telekom Srbija & 1997 & Strateška prodaja & $49 \%$ & Telecom Italia, OTE \\
\hline Slovačka & Slovak Telekom & 2000 & Strateška prodaja & $51 \%$ & Deutsche Telekom \\
\hline
\end{tabular}

Izvor: Raiffeisen Investment AG, Strategija Privatizacije, septembar 2004, str. 13

Preduzeće zbog svoje veličine ima dvodomu organizaciju upravljanja, sa Nadzornim odborom i više izvršnih direktora, koji čine Izvršni odbor. Statutom je određeno da izvršni odbor ima sedam direktora, koje je na mesto izvršnih direktora imenovao Nadzorni odbor. Prvi među jednakima, odnosno među izvršnim direktorima, koji ima ovlašćenje za zastupanje društva u pravnim poslovima je generalni direktor. Generalni direktor je zakonski zastupnik Telekom-a Srbije, koordinira rad izvršnih direktora i organizuje poslovanje.

Proces svojinske transformacije, odnosno privatizacije je od raspada SFRJ prolazio kroz nekoliko diskontinualnih faza, izazvanih promenama ekonomskog i političkog ambijenta, što je omogućilo institucionalne i vaninstitucionalne privatizacije preduzeća (Aranđelović, Petrović-Ranđelović \& Mićić, 2012). Telekom Srbija je takođe imao specifičnu svojinsku transformaciju, čiju strukturu vlasništva možemo pratiti kroz nekoliko faza: (Godišnji izveštaj o poslovanju Telekom-a Srbije, 2013, str. 11)

1. Javno preduzeće PTT saobraćaja „Srbija“, Beograd je dana 23.05.1997. godine osnovalo Preduzeće za telekomunikacije Telekom Srbija a.d., Beograd (u nastavku Telekom Srbija). Tom prilikom je predalo sva sredstva telekomunikacija, isključujući nekretnine i određena druga sredstva i obaveze. Društvo je registrovano 29.05.1997. godine kao akcionarsko društvo, osnovano na neodređeno vreme;

2. U junu 1997. godine je u okviru privatizacije dela kapitala $49 \%$ akcija prodato kompaniji Stet International Netherlands N.V., holandskoj filijali italijanske teleko- munikacione kompanije Telecom Italia (29\% akcija) i grčkoj telekomunikacionoj kompaniji Hellenic Telecommunications Organization S.A. (OTE) 20\% akcija. Zaključak stručne javnosti je da je tada u privatizaciji primenjena neodgovarajuća tehnika i loša politika privatizacije. To se obrazlaže sledećim:

- Prodaja jedinog telekomunikacionog operatera je sprovedena bez javnog poziva, tendera, a u uslovima sankcija sumnjivom neposrednom pogodbom. Kupoprodajni ugovor nije sadržao ciljeve poslovanja, niti merljive rezultate koji se očekuju od strateških partnera;

- U to doba nije postojalo regulatorno telo RATEL, pa je regulacija cena telekomunikacionih usluga ostavljena u nadležnosti novih vlasnika, s obzirom da nije obuhvaćena privatizacionim ugovorom, niti je definisana na bilo koji drugi način;

- Pored kapitala privrednog društva, privatizovana je i licenca za mobilnu telefoniju;

- Dobijenih oko 1,6 milijardi nemačkih maraka za 49\% kapitala Telekom Srbija a.d. je, po mišljenju eksperata (Paunović, 2012, str. 68), bilo manje od realne vrednosti. Ukoliko se uporedi sa privatizacijom telekomunikacionih operatora u drugim tranzicionim ekonomijama, iskustva su veoma različita. Ostvarenih $730 \$$ po priključku privatizacijom Telekom Srbija je moguće porediti, s jedne strane, sa $160 \$$ u Estoniji i $495 \$$ u Letoniji, s druge 
strane, sa $2.615 \$$ ostvarenih prodajom mađarskih telekomunikacija.Prikupljeni privatizacioni prihodi nisu se koristili za infrastrukturu, javne radove, a kamoli finansiranje daljeg razvoja telekomunikacija. Prikupljena sredstva su korišćena za penzije, socijalna davanja i pokrivanje budžetskog deficita, jednostavno za finansiranje budžetske potrošnje.

3. Za vreme Vlade premijera Z. Đinđića, u februaru 2003. godine JP PTT saobraćaja „Srbija“ otkupilo je 29\% akcija Telekom Srbija, u vlasništvu Telecom Italia. Sa neprodatih $51 \%$ i paketom od 29\%, Vlada Republike Srbije je stekla ukupno $80 \%$ akcija, dok je preostali iznos od $20 \%$ akcija ostao u grčkom vlasništvu;

4. U septembru 2010. godine su JP PTT saobraćaja „Srbija“ i Vlada Republike Srbije (24.09.2010. godine) zaključili ugovor o poklonu Telekom-a Srbije. Zaključenjem ugovora o prenosu akcija bez naknade, Republika Srbija je postala većinski vlasnik. Struktura vlasništva je i dalje bila mešovita tj. domaća svojina na $80 \%$ akcija Telekom-a Srbije, a 20\% akcija je vlasništvo grčkog manjinskog operatera;

5. Korporativni organi Telekom Srbija a.d. su decembra 2011. godine doneli odluku o sticanju sopstvenih akcija. Sopstvene akcije činile su 20\% akcija „OTE” koji je 25.01.2012. godine kao manjinski akcionar isplaćen. Od 2012. godine Telekom Srbija je postao vlasnik $20 \%$ sopstvenih akcija, ali nijedna berzanska aktivnost nije sprovedena u svim do sada navedenim svojinskim transformacijama, jer Telekom Srbija a.d. nije bio, niti je ikada funkcionisalo kao javno društvo;

6. U maju 2012. godine, odlukom Vlade Republike Srbije, a u skladu sa Zakonom, utvrđen je postupak i način prenosa besplatnih akcija privrednog društva stanovništvu Srbije, zaposlenima i bivšim zaposlenima ne samo Telekom Srbije, već i svih u PTT sistemu, kao pravnom prethodniku. Trenutni udeo vlasništva prikazan je grafički:

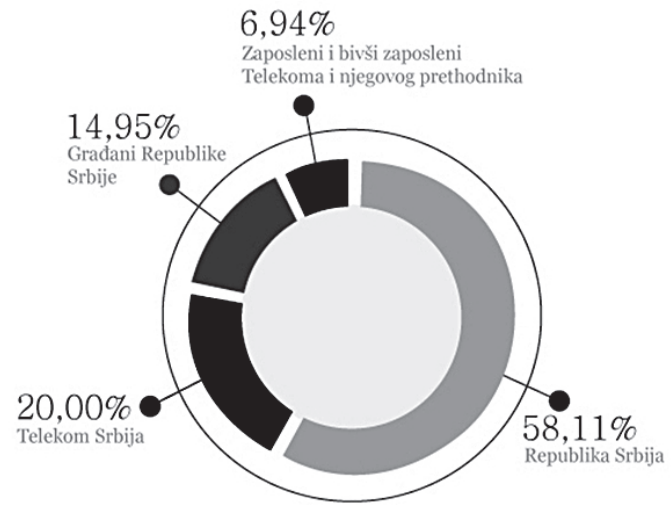

\section{Dijagram 1. Aktuelna vlasnička struktura}

7. Vlada Srbije je početkom ove godine na konkursu odabrala francusku konsultantsku kuću Lazard Freres SAS za privatizacionog savetnika. Ugovorom je predviđeno da do juna 2015. godine, jedini konsultant koji se javio na konkurs uradi Due diligence, da predloge modela privatizacije, proceni vrednost, analizira te- lekomunikaciono tržište, predoči rokove i pripremi metodološki plan privatizacije.

8. Vlada Srbije pokrenula je 25. juna 2015. godine inicijativu za privatizaciju Telekom Srbije i obavezala Ministarstvo privrede i Agenciju za privatizaciju da sprovedu taj postupak. Ipak, pre navedene odluke to je prethodno već obećano MMF-u u Memorandumu koji je poslat 11.06.2015.

9. Dana 03.07.2015. godine je, na osnovu člana 8. Uredbe o uslovima, postupku i načinu sprovođenja prodaje kapitala velikih subjekata privatizacije metodom javnog prikupljanja ponuda (Službeni glasnik RS, br. 56/2015), Agencija za privatizaciju objavila je Javni poziv za prikupljanje neobavezujućih ponuda za učešće u postupku prodaje kapitala privrednog društva Telekom Srbija a.d. Beograd prodajom akcija u vlasništvu Republike Srbije, metodom javnog prikupljanja neobavezujućih ponuda. Pravo na učešće u postupku imaju domaće i strane kompanije koje su poslednje tri godine pružale uslugu mobilne telefonije. Kao kvalifikacioni uslov za učešće u postupku traži se i da zainteresovana kompanija u poslednje tri godine ima prihode u telekomunikacionim uslugama koji su veći od 500 miliona evra ili da je u poslednjih 10 godina prikupila sredstva u iznosu većem od 500 miliona evra ili da je vrednost imovine kojom upravljaju na kraju 2014. iznosila najmanje dve milijarde evra.

\section{Tržište telekomunikacija u Srbiji i osnovni pokazatelji poslovanja}

U sledećem pasusu navodimo podatke u vezi sa srpskim tržištem telekomunikacija i osnovne finansijske pokazatelje najvećih učesnika na tržištu, kao i pojedine pokazatelje poslovanja Telekom-u u poslednjih pet godina.

Javno dostupni podaci nameću zaključak da Telekom Srbija a.d. ima:

- najveći poslovni prihod od svih telekomunikacionih operatora u Srbiji;

- poslovanje sa godišnjim neto dobicima;

- najveći broj zaposlenih od svih operatora u Srbiji (zbog fiksne mreže);

- značajne redovne uplate Republici Srbiji svih poreza i doprinosa;

- ROE koji rastu.

Na osnovu podataka, o Telekomu Srbije a.d. može se zaključiti sledeće:

- da je u pitanju visokoprofitabilna kompanija koja posluje sa godišnjim neto dobicima;

- da svojim akcionarima redovno isplaćuje redovne dividende (Republici Srbiji za pet godina - 179,5 miliona $€)$;

- da ima značajan obim investicija na godišnjem nivou;

- da redovno plaća poreze i doprinose Republici Srbiji (reda 100 miliona $€$ na godišnjem nivou);

- da je značajan donator i sponzor (reda 1,4 miliona $€$ godišnje).

Jedini pokazatelj koji je nepovoljniji za Telekom Srbija Grupu u odnosu na konkurenciju je broj zaposlenih. 


\section{REZIME}

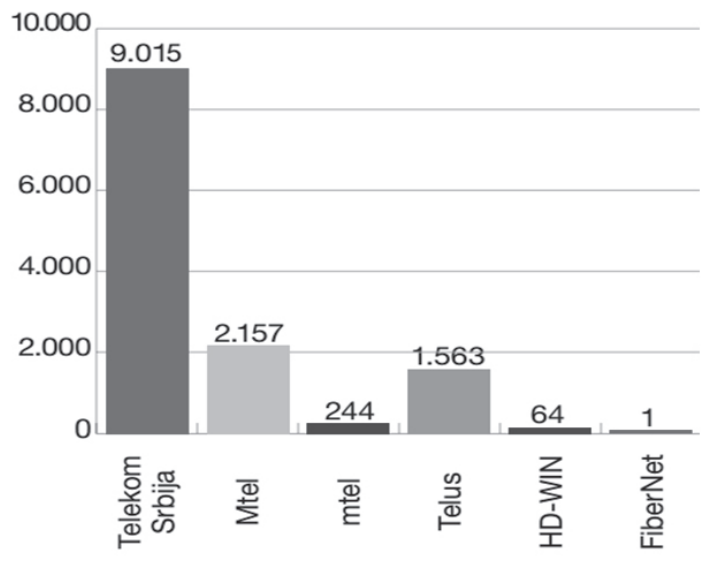

Dijagram 2. Broj zaposlenih u Telekom Srbija Grupi (matično Telekom Srbija a.d. i povezana pravna lica) na dan 31.12.2014.

Izvor: Konsolidovani izveštaj o poslovanju Telekom Srbija Grupe za 2014. godinu str. 60

Ukupno zaposlenih u svim Telekomovim kompanijama na kraju 2014. godine bilo je 13.044, a samo u matičnom preduzeću Telekom Srbija 9.015, što je znatno više od 5.340 zaposlenih u hrvatskom Telekomu ${ }^{1}$, ili 4.431 u slovenačkom ${ }^{2}$, pa čak i u mađarskom Telekomu - 10.883 (koji obuhvata i zaposlene u crnogorskom i makedonskom Telekomu ${ }^{3}$. Ono što je takođe važno jeste da troškovi za zaposlene u Telekomu Srbija nisu toliko veći od troškova u slovenačkoj ili hrvatskoj kompaniji, što ukazuje na značajno manje plate. Ovih, nešto više od 13.000 zaposlenih Telekom Srbija je koštalo 170,7 miliona evra u 2014. godini ${ }^{4}$. Više od dva i po puta manje zaposlenih u HT je koštalo prošle godine 147,2 miliona evra ${ }^{5}$, a tri puta manje zaposlenih u slovenačkom Telekomu je koštalo 139 miliona evra 6 .

Osnovni podaci o najvećim telekomunikacionim operatorima u Srbiji za 2013. godinu (Telekom Srbija, Telenor, $V I P, S B B)$ dati su u Tabelama 3 i 4.

$\mathrm{Na}$ osnovu svih iznetih podataka u vezi sa tržištem telekomunikacija u Evropi i Srbiji, izvršenih privatizacija telekomunikacionih operatora, osnovnih pokazatelja o poslovanju Telekom-a Srbije a.d. na tržištu telekomunikacija u Srbiji, u Tabeli 5 date su osnovne teze i protivteze za privatizaciju Telekom Srbija a.d.

1 Bilješke uz konsolidirana financijska izvješća Hrvatskog telekoma za godinu završenu 31. prosinca 2014. godine str. 11 dostupno na sajtu http:// www.t.ht.hr/odnosi-s-investitorima/financijska-izvjesca/\#section-nav

2 Godišnji izveštaj poslovanja Telekom Slovenije Group and Telekom Slovenije, d.d. for 2014 str. 8

3 Godišnji finansijski izveštaj Mađarskog telekoma http://www.telekom.hu/static/sw/download/IFRS_Group_2014.pdf str. 78

4 Troškovi zarada, uključujući poreze i doprinose su iznosili 20,649,655 hiljade dinara, prema Napomenama uz konsolidovane finansijske izveštaje za godinu koja se završava 31. decembra 2014. str. 36

5 Troškovi osoblja iznose 1.128 miliona kuna, bilješke uz konsolidirana financijska izvješća Hrvatskog telekoma za godinu završenu 31. prosinca 2014. godine str. 35

$6 \quad$ 138,887 miliona evra Annual Report of the Telekom Slovenije Group and Telekom Slovenije, d.d. for 2014 str. 9
Cilj svake odgovorne vlade jeste da osigura da njeni resursi, posebno oni koji imaju karakter prirodnog monopola, prilikom privatizacije ne ugroze strateška opredeljenja u politici zapošljavanja, cena, regionalnog razvoja. Istovremeno cilj je i da ugovori dodatno investiranje, jer sama država nije imala kao vlasnik novčana sredstva da to učini, i time obezbedi održiv razvoj kompanije koja je prodata. Postoje različiti modeli privatizacije, a tip privatizacije, gde je država zadržala većinsko vlasništvo je veoma čest i korišćen je u većini država kao korak prema potpunoj privatizaciji telekomunikacionog sektora. Srbija nije iskoristila pogodnost zaostajanja u procesu tranzicije, $s$ obzirom da je mogla da sagleda iskustva liberalizacija i privatizacija zemalja $\mathrm{u}$ tranziciji. Smatramo da Telekom ne treba prodavati, već izvršiti ili dokapitalizaciju, uz neophodne promene menadžmenta, broja zaposlenih i reorganizacije načina poslovanja kompanije, ili izvršiti delimičnu prodaju akcija. Iako su, prema istraživanjima, državne firme manje profitabilne od privatnih, ne postoji mnogo dokaza da privatizacija sama po sebi povećava profitabilnost. Stručna javnost često ističe da umesto direktne privatizacije (prodaje) javnih preduzeća sa neposrednim fiskalnim efektima, a neizvesnim razvojnim posledicama, često je isplativije reorganizovati javna preduzeća u cilju podizanja njihove efikasnosti i konkurentnosti (Ostojić, 2002). Koncentracija resursa, a posebno telekomunikacionog (kadrova, kapitala, know-how) je neophodna u državi koja svoju budućnost vidi u IT sektoru. Prodaja javnih preduzeća inostranim investitorima, rešava na kratki rok socijalne tenzije, jednokratno puni budžet, ali dugoročno država se trajno odriče poluga svoje razvojne politike. $U$ stvari, profitabilnost se popravlja nekoliko godina pre privatizacije, usled procesa restrukturiranja pre same prodaje privatnom sektoru. Iako su državna preduzeća sposobna da povećaju efikasnost, to poboljšanje vremenom nestaje, jer nisu suočena sa konkurentskim pritiscima da je očuvaju, ali to nije slučaj sa Telekom Srbija, koji je izložen velikoj konkurenciji. Potpuna privatizacija Telekom Srbija u svakom slučaju predstavlja prenošenje značajne ekonomske moći pod kontrolu privatne inicijative. Privatizacija ne može uvek delovati u širem društvenom interesu, niti je u mogućnosti preuzeti na sebe sve rizike poslovanja - postoji sukob između poštovanja pravila slobodne konkurencije i zadovoljenja nacionalnih interesa i potreba. Telekom Srbija ima gotovo celokupnu fiksnu telekomunikacionu infrastrukturu u Srbiji. U ovu mrežu je ulagano još od početka XX veka, tako da se ni jednoj drugoj kompaniji ne isplati gradnja ovakve mreže. Iz tog razloga, operatori koji su nastali od telefonskih operatora ubedljivo dominiraju na telekomunikacionim tržištima svih zemalja. Vlada Srbije treba da razmotri koliko je isplativo da izgubi veliki profit koji kroz dividende Telekom Srbija ide u republički budžet i mogućnost gubitka instrumenta preko koga može da podstakne razvoj domaće privrede (tako što će se kupovati proizvodi i usluge od domaćih firmi). Među vlasnicima zainteresovanih kupaca su strane države, koji će samim tim forsirati firme kooperante iz svojih zemalja, što će značiti odlivanje ne samo profita, nego i značajnog dela prihoda iz Srbije u neku drugu zemlju. Stoga bi se, gledano sa stajališta interesa nacionalne ekonomije, većinska privatizacija Telekom Srbija mogla oceniti neracionalnom i ekonomski neopravdanom. 
Tabela 3. Poslovno komercijalni rezultati poslovanja najvećih telekomunikacionih kompanija u Srbiji u 2013.

\begin{tabular}{|c|c|c|c|c|c|}
\hline & Telekom & Telenor & VIP & SBB & Ostalo \\
\hline Korisnici mobilne telefonije & $45 \%$ & $33 \%$ & $21 \%$ & $0 \%$ & $0 \%$ \\
\hline Pokrivenost teritorije mobilnom telefonijom & $90 \%$ & $90 \%$ & $84 \%$ & $0 \%$ & $0 \%$ \\
\hline Pokrivenost korisnika mobilnom telefonijom & $100 \%$ & $99 \%$ & $98 \%$ & $0 \%$ & $0 \%$ \\
\hline Pokrivenost teritorije mobilnim Internetom & $81 \%$ & $62 \%$ & $33 \%$ & $0 \%$ & $0 \%$ \\
\hline Pokrivenost korisnika mobilnim Internetom & $96 \%$ & $82 \%$ & $72 \%$ & $0 \%$ & $0 \%$ \\
\hline Korisnici mobilnog interneta & $64 \%$ & $0 \%$ & $0 \%$ & $24 \%$ & $12 \%$ \\
\hline Korisnici medijskih sadržaja & $14 \%$ & $0 \%$ & & $53 \%$ & $33 \%$ \\
\hline
\end{tabular}

Tabela 4. Finansijski rezultati poslovanja najvećih telekomunikacionih kompanija u Srbiji u 2013.

\begin{tabular}{ccccr}
\hline x 1000 RSD & Matični Telekom & Telenor & VIP & SBB \\
\hline Prihod & 86.512 .658 & 42.379 .958 & 22.616 .128 & 14.199 .427 \\
\hline Neto dobit & 15.329 .136 & 11.114 .039 & 0 & 0 \\
\hline Investicije & 13.259 .836 & 3.302 .772 & 2.289 .300 & 5.421 .985 \\
\hline
\end{tabular}

Tabela 5. Teze i protivteze privatizacije Telekom Srbija a.d.

\begin{tabular}{|c|c|c|}
\hline \multicolumn{3}{|c|}{ Za i protiv privatizacije } \\
\hline Teza & Protivteza & Dodatna napomena za razmatranje \\
\hline $\begin{array}{l}\text { Povećanje profitabilnosti Telekoma priva- } \\
\text { tizacijom zbog efikasnijeg upravljanja. }\end{array}$ & $\begin{array}{l}\text { Postavljanje profesionalnog menadžmenta iz inostran- } \\
\text { stva i eventualno smanjenje broja zaposlenih; smanje- } \\
\text { nje broja dobavljača i sklapanje opštih krovnih ugovo- } \\
\text { ra, bez posrednika. }\end{array}$ & $\begin{array}{l}\text { Za razliku od konkurencije, koja ulaže is- } \\
\text { ključivo u opremu i razvoj, profitabilnost } \\
\text { TS je ugrožena finansijskim kreditima za } \\
\text { kupovinu sopstvenih akcija. }\end{array}$ \\
\hline $\begin{array}{l}\text { Ulaganje dobijenih finansijskih sredstava } \\
\text { od prodaje Telekoma u druge investicione } \\
\text { projekte. }\end{array}$ & $\begin{array}{l}\text { Trenutno u Srbiji ne postoji oblast koja je bolja za ula- } \\
\text { ganje od telekomunikacija (što je potvrđeno dolaskom } \\
\text { stranih investitora Telenor-a i Telekom-a iz Australije, } \\
\text { investicionih fondova - SBB, sa visinom isplaćenih di- } \\
\text { vidend državi od strane Telekoma). }\end{array}$ & $\begin{array}{l}\text { Prosečna EBITDA } 10 \text { najvećih telekomu- } \\
\text { nikacionih kompanija je } 29 \% \text {, a nijedna } \\
\text { nije manja od 22\% (napomena 1). }\end{array}$ \\
\hline
\end{tabular}

Kupac stiče vlasništvo nad važnom informaciono-komunikacionom infrastrukturom (posebno zbog Interneta i velikih tehnoloških promena koje su u toku, odnosno informaciono-komunikacione revolucije).

Država gubi mogućnost kontrole i dinamike razvoja važnog infrastrukturnog sistema.

Poboljš̌an tržišno vođen sistem pružanja usluga, veća efikasnost i efektivnost u alokaciji resursa.

Eliminacija konflikta interesa, tj. da je Vlada Republike Srbije i korisnik i vlasnik.
Rukovođeni profitom, za privatne vlasnike pristupačnost telekomunikacionih usluga siromašnim regionima, selima i opštinama nema ekonomskog smisla.
Zaštita tajnosti, prodajom TS sav telekomunikacioni saobraćaj će prolaziti mrežom stranih kompanija (komunikacija građana, vojske, državne uprave, policije...).

TS je akcionarsko društvo (za razliku od drugih javnih preduzeća iz oblasti elektroprivrede, železnice i sl.) koje je preuzelo međunarodne standard poslovanja zbog prisustva stranih akcionara od osnivanja.
Transformacija upravljačkog sistema ka zapadnom korporativnom sistemu, transfer kvote know-how, pristup međunarodnim trening programima.
Za razliku od konkurencije, koja ulaže iskjučvo u opremu i razvoj, proftabilnost TS je ugrožena finansijskim kreditima za

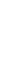
nikacionih kompanija je $29 \%$, a nijedna nije manja od $22 \%$ (napomena 1 ).

Izvor: http://www.bloomberg.com/visual-data/industries/detail/telecom-carriers

\section{LITERATURA}

Agencija za privatizaciju. (2015). Javni poziv za prikupljanje neobavezujućih ponuda za učešće u postupku prodaje kapitala privrednog društva „Telekom Srbija” a.d. Beograd prodajom akcija u vlasništvu Republike Srbije metodom javnog prikupljanja ponuda. Preuzeto 20. avgusta 2015. sa http://www. priv.rs/JavniPoziv/TelekomSrbija

Aranđelović, Z., Petrović-Ranđelović, M., \& Mićić, V. (2012). Uticaj privatizacije na održivi razvoj srpske privrede. Teme, 36(2), 443-460.
Gasmi, F., Maingard, A., Noumba, P., \& Recuero Virto, L. (2009). Impact of privatization in telecommunications - A worldwide comparative analysis. In: Economic Outlook (AEO) on „Innovation and Information and Communication Technology in Africa”. Preuzeto 12 septembra 2015. sa http://www. crninet.com/2011/b7b.pdf

Hrvatski Telekom. (2015). Konsolidirana financijska izvješća 31. prosinca 2014. godine. Preuzeto 21. avgusta 2015. sa http://www.t.ht.hr/ResourceManager/FileDownload. aspx?rId=6644\&rType=2 http://www.t.ht.hr/odnosi-s-investitorima/financijska-izvjesca/\#section-nav 
International Monetary Fund. (2015). Republic of Serbia: Letter of Intent, Memorandum of Economic and Financial Policies, and Technical Memorandum of Understanding. Preuzeto 28. jula 2015. sa http://www.imf.org/external/np/loi/2015/ srb/061115.pdf

Malinić, D., Milićević, V. (2012). Finansijska stabilnost sektora telekomunikacija u Srbiji. Telekomunikacije, broj 10, str. 2-15

Nikolić, I., \& Kovačević, M. (2014). Efekti privatizacije: empirijs$\mathrm{ka}$ analiza i rezultati na srpsku industriju. Industrija, 42(1), 63-86. doi:10.5937/industrija42-4846

Ostojić, S. (2002) Državna preduzeća - pro et contra. Ekonomika preduzeća, 50(1-2), 20-28.

Paunović, B. (2010). Privatizacija javnih preduzeća u Srbiji: doktorska disertacija. Beograd: Univerzitet Singidunum.
Službeni glasnik RS. (2012). Odluka o prenosu akcija bez naknade građanima - nosiocima prava i zaposlenima i bivšim zaposlenima Telekom Srbija. Službeni glasnik RS, br. 41/12.

Službeni glasnik RS. (2014). Zakon o pravu na besplatne akcije $i$ novčanu naknadu koju građani ostvaruju u postupku privatizacije. Službeni glasnik RS, br. 123/07, 30/10, 115/14.

Sutherland, E. (2012). A Short Note on Corruption in Telecommunications in the Balkans. Preuzeto 28. avgusta 2015. sa http:// papers.ssrn.com/sol3/papers.cfm?abstract_id=1978773

Telekom Slovenije. (2014). Annual Report of the Telekom Slovenije Group and Telekom Slovenije, d.d. for 2014. Preuzeto 28. avgusta 2015. sa http://annualreport2014.telekom.si/ business-report/financial-results-of-the-telekom-slovenije-group

\section{PRIVATIZATION OF TELECOMMUNICATIONS COMPANY TELEKOM SRBIJA IN THE VIEW OF DISPUTABLE EFFICIENCY OF CORPORATE GOVERNANCE}

\footnotetext{
Abstract:

Private ownership and market are the main postulates of successful economy and sustainable economic development, but they do not undermine the role of the state. Namely, its role is to define regulatory framework, mitigate adverse impact of selling the important network resources on the national market and sustainable economic development of a country. Management of business systems that are majority state-ownership does not differ much from the management of privately-owned business companies. Cost-effectiveness, efficiency and other economic regulations are of fundamental importance in both sectors. The specificity of corporate governance in business companies with majority state-ownership stems from paradoxical situation in which the country appears as both market participant and market regulator. The legal framework of Telekom Srbija is mostly governed by the Law on Electronic Communications and RATEL's decisions. The state-owned entities are problematic in terms of goals, as they are directed not only towards achieving profit, but they also encompass numerous non-economic, social, ecological, regional and political goals. The negative effects of such impact are in weakining the liability and motivation of corporate bodies of the stateowned companies. The paper analyses whether the motive for sale of this company stems from the poor corporate governance and whether the "passive" attitude of the state as the owner can be generalized and applied to this company.
}

\section{Key words:}

telecommunications, ownership,

Europe,

corporate governance. 